\title{
BONDING BEHAVIOR OF Eucalyptus benthamii WOOD TO MANUFACTURE EDGE GLUED PANELS
}

\author{
Sabrina A. Martins ${ }^{1}$, Cláudio H. S. Del Menezzi,^, Joana M. Ferraz ${ }^{3}$, Mário R. de Souza ${ }^{4}$
}

\begin{abstract}
The main objective of this study was to evaluate the performance of Eucalyptus benthamii Maiden et Cambage wood for the production of edge glued panels. Wood pieces with planed and sanded surfaces were bonded using cross-linking polyvinyl acetate (PVAc) and polyurethane (PUR) based adhesives, at pressures of $0.7 \mathrm{MPa}$ and 1.0 MPa. The same adhesives were used for finger jointing at a pressure of 1.5 $\mathrm{MPa}$. The bonding strength was determined through glue-line shear strength and bending test for finger jointing. According to the results, the pressure and surface preparation variables did not influence the glue-line shear strength of the adhesive PVAc, whereas for the PUR adhesive strength was influenced by the pressures and machining used. All treatments met the minimum values required by the standard; however, the highest bonding strength was found in the sample glued with PUR adhesive at a pressure of 1.0 MPa and sanded surface. The highest modulus of rupture was obtained in the samples glued using PVAc, while the modulus of elasticity was not affected by the type of adhesive used. These results enabled concluding that with regard to its technological properties assessed in the present study, E. benthamii wood is suitable for the production of edge glued panel.
\end{abstract}

Keywords: Surface preparation, adhesive, pressure, finger joint

\section{INTRODUCTION}

The advantage of eucalypts over pines species in relation to forest productivity is especially clear. However, when it comes to wood as raw material for the solid wood industry, the former has some disadvantages. The difficulties presented by eucalyptus are related to the quality of the wood that affect its mechanical processing and use, such as high shrinkage, susceptibility to collapse and the presence of growth stresses (Rocha 2000). Among the genus' species, Eucalyptus grandis has stood out as one of the most planted in Brazil and worldwide, and its versatile wood is suitable for multiple uses.

The climate in the region of the Santa Catarina State Plateau in southern Brazil is unsuitable for planting eucalyptus, especially due to the incidence of frost. However, some species such as Eucalyptus dunnii and Eucalyptus benthamii have shown significantly higher resistance compared to other species of the genus. Studies indicate that $E$. benthamii has shown satisfactory growth and, as expected, resistance to frost in experimental plantations in southern Brazil (Higa and Pereira 2003, Pereira et al. 1997, Higa and Carvalho 1990). Other studies also emphasize the use of wood of this species for energy purposes (Lima et al. 2007), production of kraft pulp (Alves et al. 2011) and plywood (Martins et al. 2011a). Recently, the effect of machining processing on the surface roughness of wood from this species was also studied (Martins et al. 2011b). In addition, the Southern region of Brazil stands out for its strong timber

\footnotetext{
PhD Candidate in Forest Science, Department of Forest Engineering, Faculty of Technology, University of Brasilia, Brasília, DF, BRAZIL. sabrinaand@gmail.com

${ }^{2}$ Adjunct Professor, Dr., Department of Forest Engineering, Faculty of Technology, University of Brasilia, Brasília, DF, BRAZIL.

${ }^{3}$ Forest Engineer, MSc, Department of Forest Engineering, Faculty of Technology, University of Brasilia, Brasília, DF, BRAZIL. joanamendesferraz@gmail.com

${ }^{4}$ Wood Scientist, PhD, Forest Products Laboratory, Brazilian Forest Service, Ministry of Environment, 70818-900, Brasília, DF, BRAZIL. mario.souza@florestal.gov.br

Corresponding author: ^cmenezzi@unb.br

Received: 11.05. 2012 Accepted: 14.09. 2012
} 
industry and export market. In 2010 it accounted for $60 \%$ and $64 \%$ of the amount and total volume of Brazilian exports of manufactured goods and wood manufactured goods respectively (Soares et al. 2011), thus contributing to the research and development of species with potential for the region in question.

In order to add value to the primary product, higher added value products can be an alternative use for the species E. benthamii. Among the most outstanding products in economic terms are those used by the furniture industry, such as edge glued panels (EGP). The great advantage of this panel is the use of small-diameter logs, which may result from the first thinning, and the use of waste from other processes. In the case of edge glued panels, the most frequently used adhesive is still polyvinyl acetate (PVA). However, due to advances in the chemical industry, there has been a significant development in new adhesives technology, hence the need to assess the adhesives best suited for different types of wood (Lima et al. 2008). Furthermore, the use of adhesives should also take into account the economical aspect, since in some processes cost is a limiting factor in product development, and still, the environmental aspect, mainly regarding the volatile organic compounds (VOC) emission standards.

The wood-gluing process is influenced by several factors, which may be related to the characteristics of both the adhesive and the wood, as well as to the control parameters of the process. The amount of research on the topic is significant. The aspects most frequently addressed refer to the bonding strength of different wood species, with emphasis on Pinus and Eucalyptus, different density levels, different weights and pressures used in the gluing process (Lima et al. 2008, Plaster et al. 2008, Lobão and Gomes 2006, Nascimento et al. 2002, Serrano 2009). Research related to surface preparation for gluing is still scarce in Brazil. In other countries, research focuses on assessing surface roughness vis-à-vis different machining methods, and some relate this property to the use of finishing products (Hernández and Cool 2008a, Kilic et al. 2006, Burdurlu et al. 2005, Ozdemir and Hiziroroglu 2007, Sulaiman et al. 2009, Hernández and Cool 2008b) and others to bonding strength (Özçifçi and Yapici 2008a, Murmanis et al. 1983).

In this context, the objective of the study was to assess the gluing quality of Eucalyptus benthamii Maiden et Cambage wood for the production of EGP. Specifically, the study assessed the effect of different adhesives, pressures and preparation of the wood surface on gluing strength, as well as the effect of different adhesives on finger-joint strength.

\section{MATERIAL AND METHOD}

\section{Log sampling and sawing}

The material used in the study was provided by Klabin SA, and comes from the experimental planting area in the municipality of Otacílio Costa, Santa Catarina State, Brazil. The first log of 50, 12-year old $E$. benthamii trees was used in the sawing process. The criterion used for selecting the logs was the low incidence of defects such as warping and checking. From this material, thirty lumber pieces 3,000 $\mathrm{mm}$ long, $40 \mathrm{~mm}$ thick and variable widths were obtained. Afterwards, the lumber material was kiln dried, and then it was kept in a climate-controlled chamber (temperature $20 \pm 2^{\circ} \mathrm{C}$ and relative humidity $65 \pm 2 \%$ ) for a period of six months.

\section{Edge gluing}

The lumber material whose plane orientation was predominantly radial, was cut into $700 \mathrm{~mm}$-long, $55 \mathrm{~mm}$-wide and $25 \mathrm{~mm}$ - thick pieces and submitted to the surface preparation processes. The sanded surface was obtained by manually sanding the pieces, where a standard procedure was defined. The pieces were rubbed 40 times parallel to the grain of the wood using 60 grit sandpaper approximately 1.5 $\mathrm{m}$ long, fixed on a workbench. The planing procedure was realized in a planer provided with 2 knives with rotation of the spindle $3440 \mathrm{rpm}$. The depth of the planer cut was approximately $0.6 \mathrm{~mm}$. 
Multibond Advantage II, a cross-linking polyvinyl acetate emulsion adhesive (PVAc) (D4 according to EN 214) with the addition of catalyst in the proportion of $6 \%$ of the weight, and the polyurethane-based (PUR) Purweld 1052 (monocomponent) adhesive, were used at spread rate of $200 \mathrm{~g} / \mathrm{cm}^{2}$ for gluing the pieces. The viscosity and solids content of the Multibond Advantage II adhesive were 3500-4500 cP, and 53.9-56.3\% respectively (Franklin International 2004). The Purweld 1052 adhesive had a viscosity of $5000 \mathrm{cP}$ and solids content of $100 \%$ (Purbond 2007). Pressing was performed using a hydraulic press at pressures of $0.7 \mathrm{MPa}$ and $1.0 \mathrm{MPa}$, at room temperature. The pressing times for Multibond Advantage II and the 1052 Purweld adhesives were 360 and 90 minutes respectively. Table 1 shows the treatments and experimental designs used in this assessment.

Table 1. Experimental design.

\begin{tabular}{ccccc}
\hline Adhesive $^{1}$ & $\begin{array}{c}\text { Surface } \\
\text { preparation }\end{array}$ & $\begin{array}{c}\text { Pressure } \\
(\mathrm{MPa})\end{array}$ & \# Specimen & Treatment \\
\hline \multirow{3}{*}{ PVAc } & Plane & 0.7 & 20 & $\mathrm{~T} 1$ \\
\cline { 2 - 5 } & & 1.0 & 20 & $\mathrm{~T} 2$ \\
\cline { 3 - 5 } & Sandpaper & 0.7 & 20 & $\mathrm{~T} 3$ \\
\cline { 3 - 5 } & \multirow{2}{*}{ Plane } & 0.7 & 20 & $\mathrm{~T} 4$ \\
\cline { 3 - 5 } PUR & & 1.0 & 20 & $\mathrm{~T} 5$ \\
\cline { 2 - 5 } & \multirow{2}{*}{ Sandpaper } & 0.7 & 20 & $\mathrm{~T} 6$ \\
\cline { 3 - 5 } & & 1.0 & 20 & $\mathrm{~T} 7$ \\
\hline
\end{tabular}

Note. 1PVAc, cross-linking polyvinyl acetate; PUR, polyurethane

The glued pieces were placed in a climate-controlled chamber at a temperature of $20 \pm 2^{\circ} \mathrm{C}$ and relative humidity of $65 \pm 2 \%$ for 20 days, and were finally cut into test specimen according to ASTM (American Society for Testing and Materials) D5751 (1995). The specimen were tested on an universal test machine Instron model 1127 at a constant speed of $12.8 \mathrm{~mm} / \mathrm{min}$ and glue-line shear strength $\left(\mathrm{f}_{\mathrm{gv}, 0}\right)$ was assessed. After rupture, the percentage of wood failure was assessed visually with the help of transparent blades in the same sizes as the gluing area of the test samples. The transparent blades were previously crosshatched in 100 equal parts, so that each part represented $1 \%$ of the glued area. Subsequently, the test samples were taken to a drying chamber at a temperature of $103^{\circ} \mathrm{C} \pm 2^{\circ} \mathrm{C}$, in order to determine the moisture content according to NBR 7190 (1997). Test samples with moisture other than $12 \%$ (between $10 \%$ and $20 \%$ ) had their strength corrected to the $12 \%$ standard moisture.

\section{Finger joint}

The pieces used were $200 \mathrm{~mm}$ long, $70 \mathrm{~mm}$ wide and $30 \mathrm{~mm}$ thick and were weighed and measured to determine the density. Once the density values had been calculated, the pieces were classified, so that pieces of similar density could be glued together. The geometry of the finger was $10 \mathrm{~mm}$ long, $6 \mathrm{~mm}$ pitch, $1 \mathrm{~mm}$ tip width and slope of approximately $31^{\circ}$. The same adhesives used in edge-gluing, both applied at spread rate of $200 \mathrm{~g} / \mathrm{m}^{2}$ were used in finger jointing. The assembly pressure of $1.5 \mathrm{MPa}$ was applied for two minutes.

The glued pieces were kept under a controlled temperature of $20 \pm 2^{\circ} \mathrm{C}$ and relative humidity of 65 $\pm 2 \%$ for 10 days. Test samples $307.2 \mathrm{~mm}$ long, $19.2 \mathrm{~mm}$ wide and $12.8 \mathrm{~mm}$ thick were subsequently produced, according to ASTM D5572 (1995). Finger joint orientation in relation to load direction at the time of the test was vertical and a four-point bending schedule was used. Twenty test samples glued with 
PVAc adhesive and 20 test samples glued with PUR adhesive were tested for bending using a universal test machine Instron model 1127. The modulus of rupture $\left(\mathrm{f}_{\mathrm{m}}\right)$ and the modulus of elasticity $\left(\mathrm{E}_{\mathrm{M}}\right)$ were estimated according to ASTM D5572 (1995) and ASTM D198 (1997) respectively.

\section{Image analysis}

Scanning electron microscope (SEM) images of planed and sanded surfaces prior to gluing were analyzed in order to identify differences in the surfaces prepared using different machining processes. The profile of the glue line for each surface (sanded and planed) was also evaluated. These images were obtained in a low-vacuum SEM, model Quanta 2003D - Dual Beam (FEI Company), with accelerating voltage of $20 \mathrm{kV}$ and at a working distance of $7.7 \mathrm{~mm}$ to $10.1 \mathrm{~mm}$ from the sample.

\section{Analysis of the experiment}

The results of the shear testing were analyzed by full factorial design $(2 \times 2 \times 2)$, where the effect of the adhesive (PVAc and PUR), of the procedure used for preparing the surface (plane and sandpaper) and of the pressure $(0.7 \mathrm{MPa}$ and $1.0 \mathrm{MPa})$ on the glue-line shear strength $\left(\mathrm{f}_{\mathrm{gv}, 0}\right)$ was assessed. This analysis was followed by Tukey test at $5 \%$ was used to differentiate the means. The results of the bending (fm and EM) were analyzed using one-way analysis of variance (ANOVA) in order to identify the effect of adhesive type.

\section{RESULTS AND DISCUSSION}

\section{Glue line shear strength}

The average density of the wood pieces was about $769 \mathrm{~kg} / \mathrm{m}^{3}$, and the average moisture content was $13.4 \%$. Figure 1 shows the means and standard deviations of the shear strength for each treatment tested. The values have already been corrected for the moisture content of $12 \%$, as established by the standard. Initially, a general analysis between treatments was performed by analysis of variance and Tukey's test. This analysis enabled observing two different groups, with a higher strength value found for treatment T8 and lower values for treatments T5, T6 and T7. Pursuant to ASTM D5751 (1995), the average shear strength of each treatment should reach $60 \%$ of the shear strength of solid wood. According to Cunha et al. (2009), the shear strength of solid wood from the same batch of $E$. benthamii used in this study is 12.7 MPa, ranging from 14.0 to $10.8 \mathrm{MPa}$. Thus, in accordance with the standard, all treatments tested reached the minimum value of shear strength (Figure 1).

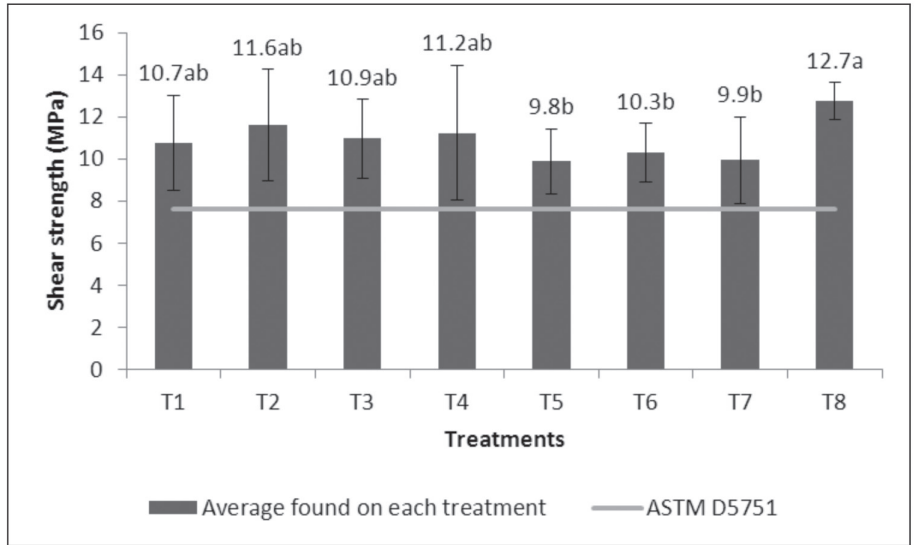

Figure 1. Mean and standard deviation values of glue-line shear strength for different treatments and value required by ASTM D5751.

Note. Means followed by the same letters are not statistically different by Tukey's test at the $1 \%$ probability level. T1 - PVAc, plane, 0.7; T2 - PVAc, plane, 1.0; T3 - PVAc, sandpaper, 0.7; T4 - PVAc, sandpaper; 1.0; T5

- PUR, plane, 0.7; T6 - PUR, plane, 1.0; T7 - PUR, sandpaper, 0.7; T8 - PUR, sandpaper, 1.0 
Wood failure percentage for all treatments and the minimum percentage set by ASTM D5751 (1995) is shown in figure 2 . The standard requires that the mean of each treatment reach $60 \%$ of wood failure, which was achieved by all treatments. The analysis of wood failure percentage shows a greater efficiency of the adhesive, with a higher percentage obtained. Thus, it can be said that PVAc adhesive was more efficient for gluing $E$. benthamii compared to PUR adhesive, since the general mean for PVAc adhesive was $95.1 \%$ while for PUR adhesive it was $78.9 \%$.

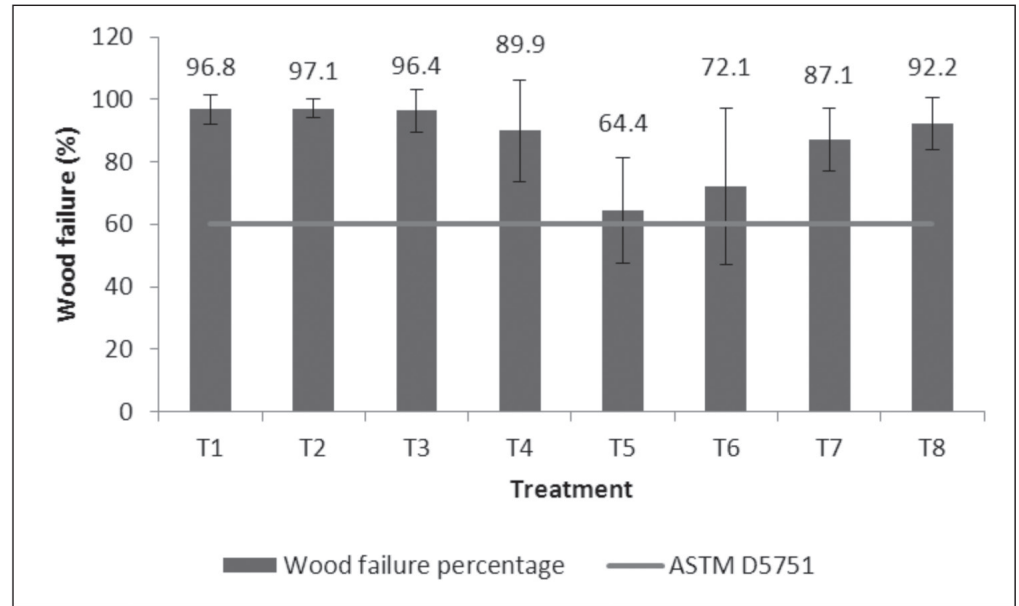

Figure 2. Wood failure percentage in each treatment.

Note. T1: PVAc, plane, 0.7; T2 - PVAc, plane, 1.0; T3 - PVAc, sandpaper, 0.7; T4 - PVAc, sandpaper, 1.0; T5 - PUR, plane, 0.7; T6 - PUR, plane, 1.0; T7 - PUR, sandpaper, 0.7; T8 - PUR, sandpaper, 1.0.

Wood failure percentages found in treatments $\mathrm{T} 5$ and $\mathrm{T} 6$ are notable for their inferiority in comparison to other treatments. Both were glued using PUR adhesive and their surfaces prepared with a plane, indicating low bonding efficiency when these variables are used. Studies on wood percentage values for the genus Eucalyptus glued with PVAc adhesive shows that these values can vary widely depending on the species and parameters used in the gluing process. In the present study, the values found for PVAc adhesive were higher than those observed in the literature (Lima et al. 2008, Vital et al. 2006, Plaster et al. 2008), excepting the value found by Pincelli et al. (2002).

A factorial analysis was subsequently performed to assess, separately, the effect of the adhesive, of the surface pressure and of preparation on the bonding strength, and respective interactions. This analysis showed that the pressure variable influenced the bonding strength as well as the surface $\mathrm{x}$ adhesive interaction and the triple adhesive $\mathrm{x}$ pressure $\mathrm{x}$ surface interaction (Table 2). 
Table 2. Summary result of the analysis of variance for the estimated variables.

\begin{tabular}{lc}
\hline \multicolumn{1}{c}{ Variable } & Significance \\
\hline Adhesive & $0.203^{\mathrm{NS}}$ \\
Surface & $0.086^{\mathrm{NS}}$ \\
Pressure & $0.001^{* *}$ \\
Adhesive x Surface & $0.049^{*}$ \\
Adhesive x Pressure & $0.114^{\mathrm{NS}}$ \\
Surface x Pressure & $0.171^{\mathrm{NS}}$ \\
Adhesive x Surface x Pressure & $0.029^{*}$
\end{tabular}

Note. NS Non-significant; ** Significant at the $1 \%$ probability level;

* Significant at the $5 \%$ probability level.

Figure 3 shows the behavior of the adhesive, pressure and surface variables individually analyzed. The adhesive and surface variables showed no significant difference, while the pressure variable showed a significant difference. The average result of the glue line strength for the PVAc adhesive found in this study (11.1 MPa) was higher than those found by Lima et al. (2008) (7.4 and 7.9), Serrano (2009) (7.5), Vital et al. (2006) (8.7 and 9.6), and Serpa et al. (2003) (10.7) when assessing shear strength for the genus Eucalyptus using PVAc adhesive. This comparison therefore shows that bonding of $E$. benthamii wood with PVAc adhesive reached values similar to those of other Eucalyptus species. The result found for PUR adhesive was higher than that found by Özçifçi and Yapici (2008a), when investigating the bond strength of five species using PVAc and PUR adhesives.

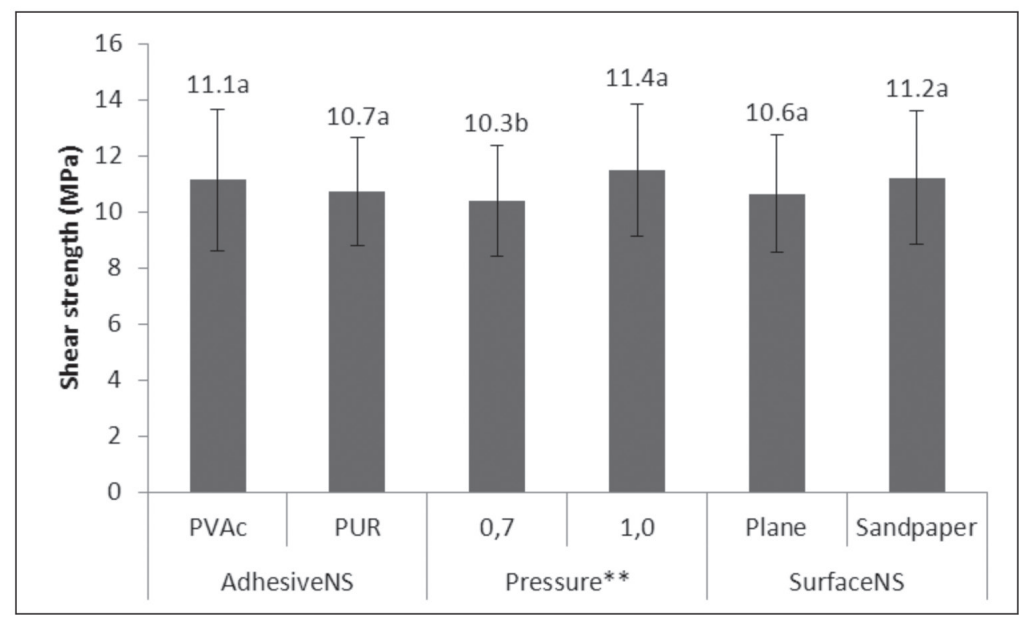

Figure 3. Effects of adhesive type, assembly pressure and surface preparation on glue-line shear strength.

Note. Means followed by the same letters are not statistically different at the $1 \%$ level within each variable; NS Non-significant; ** Significant at $1 \%$ level 
The pressure variable when analyzed separately showed a significant difference, indicating that the pieces at a pressure of 1.0 MPa showed higher bonding strength than those glued at a pressure of 0.7 MPa. A similar result was obtained by Nascimento et al. (2002), who found better bonding performance for Pinus and Eucalyptus using the pressure of 1.0 MPa. The results found in this study also confirm the recommendation made by River and Okkonen (1991), Corrêa (1997) and Muenchow (2002) to glue medium density wood at pressures between 0.9 and $1.3 \mathrm{MPa}$. On the other hand, when only the surface preparation variable was considered, no significant difference was found between planed and sanded surfaces. Still on the factorial analysis, the adhesive x surface interaction was significant, indicating that the effect of the adhesive depends on the type of surface, as shown in table 2 and figure 4.

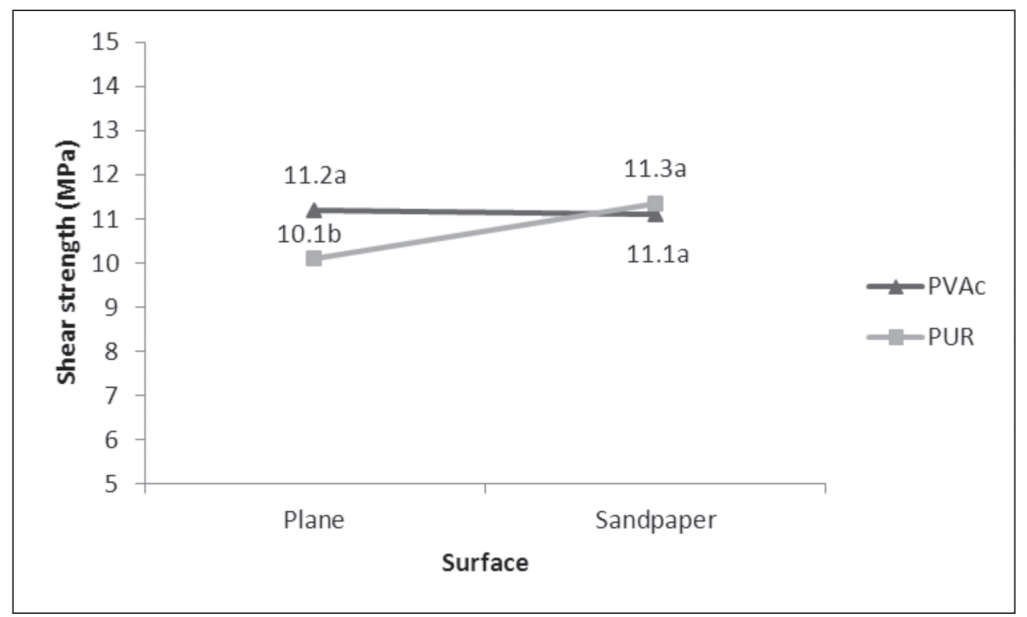

Figure 4. Interaction effects of adhesive type and surface on the glue-line shear strength.

Note. Means followed by the same letters are not statistically different within each adhesive

The analysis of figure 4 shows a different behavior between PVAc and PUR adhesives in relation to different surfaces used in the study. Shear strength for the PVAc adhesive was statistically the same when using either plane or sandpaper to prepare the wood surface. Thus, for the PVAc adhesive both the planning and sanding processes showed similar bonding features for E. benthamii wood. As a result, companies can choose the machining system that best suits their production process, taking into account the availability of equipment. For PUR adhesive, the bonding strength of the sanded surface was significantly higher than for the planed surface, which enables inferring that PUR adhesive was directly influenced by surface quality.

As seen in table 2, the triple interaction adhesive $\mathrm{x}$ pressure $\mathrm{x}$ surface also showed a significant difference. The effect of pressure and surface separately within each adhesive was studied for the purpose of obtaining a more detailed analysis. Table 3 shows the average bonding strength of each variable analyzed for PVAc and PUR adhesives. According to the statistical analysis, no significant difference was found for different pressures and different surfaces when PVAc adhesive was used, while for PUR adhesive there was significant difference between different pressures as well as between different surfaces. 
Table 3. Mean glue-line shear strength $(\mathrm{MPa})$ in each variable analyzed for PVAc and PUR adhesives.

\begin{tabular}{ccccc}
\hline \multirow{2}{*}{ Adhesive } & \multicolumn{2}{c}{ Pressure (MPa) } & \multicolumn{2}{c}{ Surface } \\
\cline { 2 - 5 } & 0.7 & 1.0 & Plane & Sandpaper \\
\hline PVAc & $10.86 \mathrm{a}$ & $11.42 \mathrm{a}$ & $11.18 \mathrm{~A}$ & $11.10 \mathrm{~A}$ \\
PUR & $9.91 \mathrm{~b}$ & $11.53 \mathrm{a}$ & $10.10 \mathrm{~B}$ & $11.33 \mathrm{~A}$ \\
\hline \multicolumn{2}{l}{$\begin{array}{l}\text { Note. Numbers followed by the same letters are not statistically } \\
\text { different at } 1 \% \text { significance level within each adhesive. }\end{array}$}
\end{tabular}

The mean values found in this study for the test specimens glued using PVAc adhesive at pressures of 0.7 and 1.0 MPa were higher than the values found by Lima et al. (2008), who testing E. urophyla and E. camaldulensis samples obtained 7.4 MPa and 7.9 MPa, respectively, but lower than those found by Plaster et al. (2008), who obtained 13.7 MPa with Eucalyptus sp. Both used a pressure of approximately 1.2 MPa and PVAc adhesive. The results achieved for treatment using PVAc adhesive and sanded surface can be partially compared to the result found by Vital et al. (2006). The authors assessed the gluing of E. saligna and E. grandis using PVAc adhesive and surface sanded with 80-grit sandpaper. The values found were $9.7 \mathrm{MPa}$ and $8.7 \mathrm{MPa}$ for $E$. saligna and E. grandis respectively, which are considerably lower than those found in this study.

Table 4 shows the mean values of shear strength for PVAc and PUR adhesives in each variable analyzed. PVAc proved to be a very practical and easy to use adhesive, as no change occurred in the shear strength as a result of increased bonding pressure, regardless of the surface. On the other hand, the shear strength of PUR adhesive was higher on sanded surface when the bonding pressure increased, but was not affected by pressure on planed surface.

Table 4. General behavior of glue-line shear strength for PVAc and PUR adhesives.

\begin{tabular}{cccc}
\hline \multirow{2}{*}{ Adhesive } & Surface & \multicolumn{2}{c}{ Pressure (MPa) } \\
\cline { 2 - 4 } & & 0.7 & 1.0 \\
\hline \multirow{2}{*}{ PVAc } & Plane & $10.76 \mathrm{a}$ & $11.61 \mathrm{a}$ \\
\cline { 2 - 4 } & Sandpaper & $10.96 \mathrm{~A}$ & $11.24 \mathrm{~A}$ \\
\hline \multirow{2}{*}{ PUR } & Plane & $9.88 \mathrm{a}$ & $10.31 \mathrm{a}$ \\
\cline { 2 - 4 } & Sandpaper & $9.93 \mathrm{~B}$ & $12.74 \mathrm{~A}$ \\
\hline
\end{tabular}

Note. Means followed by the same letters at same line are not statistically different at the $1 \%$ level. 
This result found for PUR adhesive can best be explained by spreading thereof, provided by increased pressure associated with the grooves produced by the sandpaper on the sanded surface (Figure 5B), characteristics that were not found in the planed surface (Figure 5A). A similar phenomenon was observed by Moura and Hernandez (2005), who affirm that the grooves contribute to the gluing process as they offer better conditions for spreading the adhesive, since it speeds liquid conduction parallel to the wood grain. Therefore, one can infer that the combination of higher pressure with the presence of grooves alone lead to significant improvement in the gluing performance. However, the same is not true for the treatment of sanded surface and pressure of $0.7 \mathrm{MPa}$. The main advantage of PUR adhesive over PVAc adhesive is the curing time, which makes the former more advantageous from the standpoint of productivity. On the other hand, it requires specific equipment for its application as well as extra care, given the short open time, which requires special procedures.

Figure $5(\mathrm{C}, \mathrm{D})$ shows the glue line of sanded and planed pieces, where it is possible to see that the planed surface showed a straighter line compared to the glue line of the sanded surface, thereby confirming the presence of grooves on the sanded surface, which was not observed in the planed surface (Figure $5 \mathrm{~A}$ and B), as also found by Martins et al. (2011b), when analyzing planed and sanded surfaces of $E$. benthamii wood.
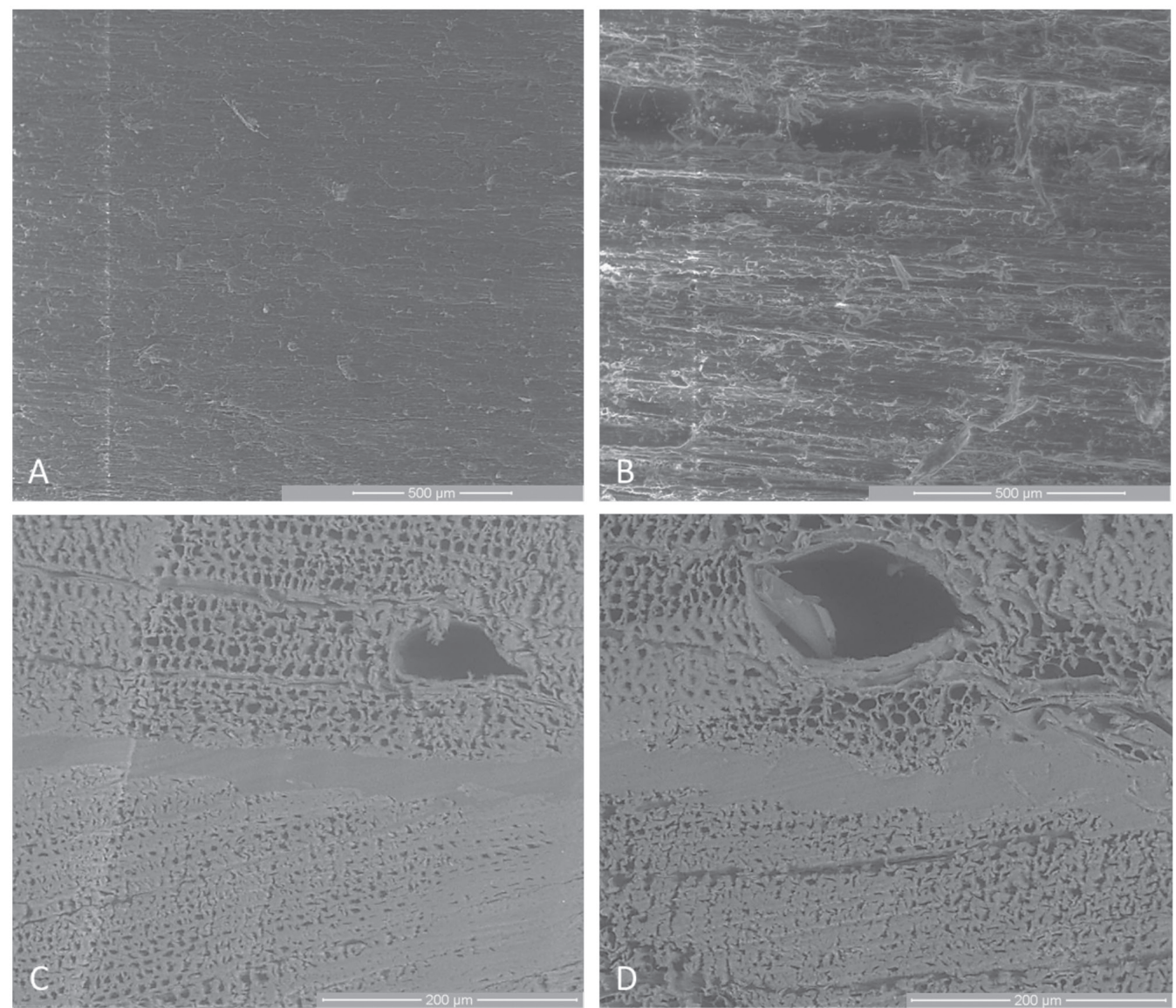

Figure 5. SEM image of the planed surface (A) and sanded surface (B), as well as of the side face of the glue line shown by E. benthamii planed (C) and sanded (D) boards. 


\section{Static bending strength}

The average moisture content of the boards used in finger jointing was $13.5 \%$ and the average density was $685 \mathrm{~kg} / \mathrm{m}^{3}$. The average values of modulus of rupture $\left(\mathrm{f}_{\mathrm{m}}\right)$ and modulus of elasticity $\left(\mathrm{E}_{\mathrm{M}}\right)$ in the static bending test found in each treatment tested are shown in table 5 .

Table 5. Values of modulus of rupture and modulus of elasticity for PUR and PVAc treatments.

\begin{tabular}{ccc}
\hline Adhesive & $\mathrm{f}_{\mathrm{m}}(\mathrm{MPa})$ & $\mathrm{E}_{\mathrm{M}}(\mathrm{MPa})$ \\
\hline PVAc & $68.05 \mathrm{a}$ & $16158 \mathrm{a}$ \\
PUR & $46.49 \mathrm{~b}$ & $16480 \mathrm{a}$
\end{tabular}

Note. Means followed by the same letters at same column are not statistically different at the $1 \%$ level.

Based on the statistical analysis, PVAc adhesive showed higher bonding strength (MOR) than PUR adhesive. Lower strength was found by Özçifçi and Yapici (2008b) in bending tests using different species, adhesives and finger configurations. Even the samples with finger length of $14 \mathrm{~mm}$ were still inferior to those achieved in this study. Finger joints glued with PVAc adhesive were also studied by Vassiliou et al. (2007), where samples of Fagus sylvatica wood were subjected to bending tests. Class D1 and D2 adhesives showed lower modulus of rupture, while for the class $\mathrm{C}$ adhesive the modulus of rupture value was higher than that of adhesive D4 analyzed in this study. The bending strength shown by PVAc adhesive was similar to that found by Karastergiou et al. (2006), when evaluating the flexural strength of specimens with equal length fingers. The bonding performance reported by Vrazel and Sellers $\mathrm{Jr}$ (2004) in bending tests using PUR adhesive was far higher than that found in this study. However, it should be borne in mind that the length of the finger was $15 \mathrm{~mm}$; then, higher strengths are expected, since the length of the fingers is directly related to the performance of the finger joint. Considering the static bending strength of $E$. benthamii wood found by Cunha et al. (2009), which was $78.3 \mathrm{MPa}$, the gluing efficiency of PVAc adhesive was $87 \%$, while for PUR adhesive it was $59 \%$, i.e., the gluing efficiency of PVAc adhesive was higher than that of PUR adhesive. The lower efficiency of the test specimens glued with PUR adhesive may be associated with the process, e.g. the application process. Due to high reactivity, the open time is extremely short, making it difficult to spread the adhesive, depending on the application process.

In relation to the modulus of elasticity, according to statistical analysis (Table 5), no significant difference was found between treatments, indicating that both show similar stiffness properties. The modulus of elasticity values are higher than the vast majority of the values found by other researchers (Özçifçi and Yapici 2008b, Karastergiou et al. 2006, Vassiliou et al. 2007, Vrazel and Sellers Jr 2004). It was also observed that PVAc adhesive system showed a plastic regime, resulting in a higher modulus of rupture when compared with PUR adhesive, while PUR adhesive presented brittle rupture, where the load in the proportional limit was very close to the rupture load. Under ASTM D5572 (1995) all the specimens tested in each treatment must reach on the bending test a minimum value of $13.8 \mathrm{MPa}$ in its modulus of rupture. Figure 6 shows the modulus of rupture values found in each specimen tested in the PVAc and PUR treatments respectively. The results show that for both PUR adhesive and PVAc adhesive, all samples tested reached the minimum value required by the standard, thus confirming approval of $E$. benthamii wood according to ASTMD5572 (1995), under the conditions established in the present study. 

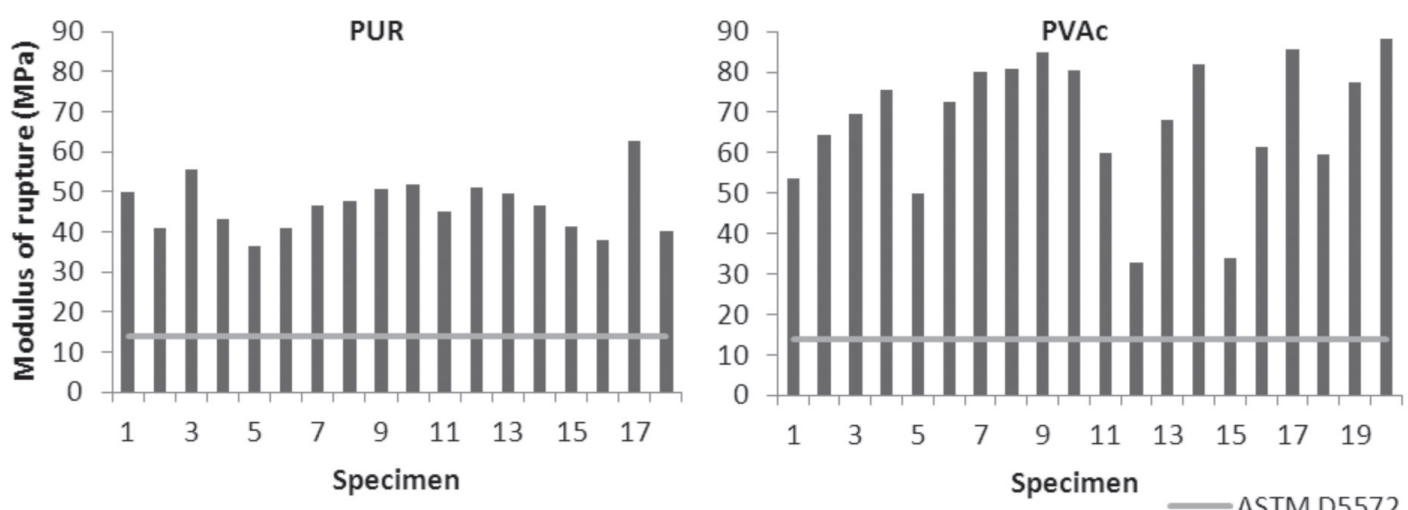

Figure 6. Modulus of rupture values found in each test specimen in PUR and PVAc treatments and value required by ASTM D5572 (1995).

\section{CONCLUSIONS}

In the glue-line shear testing all treatments reached the minimum values required by the standard, it terms of both strength and wood failure; however, the higher bonding strength was found in the specimen glued with PUR adhesive at a pressure of 1.0 MPa and sanded surface.

The shear strength obtained by PVAc adhesive was not influenced by pressure or by the surface preparation; for PUR adhesive the pressure and machining used in the study influenced the bonding strength.

The higher bending strength in the finger joint was found in samples glued with PVAc adhesive; however, the modulus of elasticity was not influenced by the type of adhesive used. Both treatments reached the minimum values required by the standard.

\section{ACKNOWLEDGEMENTS}

To National Council for Scientific and Technological Development (CNPq) for the Master's degree scholarship in Forest Science granted to the first author; to the Otacílio Costa Unit of KLABIN S.A for supplying the lumber; and to the Ballistic Department of the Brazilian Federal Police for scanning electron microscope images. 


\section{REFERENCES}

ABNT. Associação Brasileira de Normas Técnicas. 1997. Projeto de estruturas de madeira. NBR 7190. Brasil. 107 p.

Alves, ICN.; Gomide, JL.; Colodette, JL.; Silva, HD. 2011. Caracterização tecnológica da madeira de Eucalyptus benthamii para produção de celulose kraft. Ciência Florestal 21(1):167-174.

ASTM. American Society for Testing and Materials. 1995. Standard specification for adhesives used for finger joints in nonstructural lumber products. ASTM D5572. 17 p.

ASTM. American Society for Testing and Materials. 1995. Standard specification for adhesives used for laminate joints in nonstructural lumber products. ASTM D5751. $11 \mathrm{p}$.

ASTM. American Society for Testing and Materials. 1997. Standard test methods of static tests of lumber in structural sizes. ASTM D198. $26 \mathrm{p}$.

Burdurlu, E.; Usta, I.; Ulupinar, M.; Aksu, B.; Erarslan, Ç. 2005. The effect of the number of blades and grain size of abrasives in planing and sanding on the surfasse roughness of European black pine and Lombardy poplar. Turkish Journal of Agriculture \& Forestry 29(4):315-321.

Corrêa, CG. 1997. Técnicas de Colagem de Madeiras com Adesivos Vinílicos. Borden Química Indústria e Comércio Ltda. Brasil. 68 p.

Cunha, AB.; Martins, SA.; Anjos, RAM. 2009. Caracterização da madeira de Eucalyptus benthamii. Universidade do Planalto Catarinense - UNIPLAC. (não publicado)

Franklin International. 2004. Boletim Técnico Multibond Advantage 2. Franklin International Adesivos para a indústria moveleira e madeireira. EUA. 3 p.

Hernández, RE.; Cool, J. 2008a. Effects of cutting parameters on surface quality of paper birch wood machined across the grain with two planning techniques. Holz Roh Werkst 66(2):147-154.

Hernández, RE.; Cool, J. 2008b. Evaluation of three surfacing methods on paper birch wood in relation to water-and solvent-borne coating performance. Wood and Fiber Science 40(3):459-469.

Higa, AR.; Carvalho, PER. 1990. Sobrevivência e crescimento de doze espécies de eucalipto em Dois Vizinhos, Paraná. Silvicultura 3(42):459-461.

Higa, RCV.; Pereira, JCD. 2003. Usos Potenciais do Eucalyptus benthammii Maiden et Cambage. Comunicado Técnico, Colombo: Embrapa Florestas. 4p.

Karastergiou, S.; Barboutis, J.; Vassiliou, V. 2006. Effect of the PVA gluing on bending strength properties of finger jointed turkey oakwood (Quercus cerris L.). Holz als Roh - und Werkstoff 64(4):339340.

Kilic, M.; Hiziroglu, S.; Burdurlu, E. 2006. Effect of machining on surface roughness of wood. Building and Environment 41(8):1074-1078.

Lima, CKP.; Mori, FA.; Mendes, LM.; Trugilho, PF.; Mori, CLSO. 2008. Colagem da madeira de clones de Eucalyptus com três adesivos comerciais. Scientia Forestalis 36(77):73-77. 
Lima, EA.; Silva, HD.; Magalhães, WLE.; Lavoranti, OJ. 2007. Caracterização individual de árvores de Eucalyptus benthamii para uso energético. Boletim de pesquisa e desenvolvimento, Colombo: Embrapa Florestas. 25 p.

Lobão, MS.; Gomes, A. 2006. Qualidade da adesão de madeira de eucalipto em corpos-de-prova colados em dois diferentes planos e densidades. Cerne 12(2):194-200.

Martins, SA.; Cunha, AB.; Oliveira, J. 2011a. Avaliação da qualidade da colagem de painéis compensados de Eucalyptus benthamii Maiden et Cambage. In: Proceedings $1^{\circ}$ Congresso IberoLatinoAmericano da Madeira na Construção, 2011, Coimbra. $1^{\circ}$ Congresso Ibero-LatinoAmericano da Madeira na Construção. Coimbra: Departamento de Engenharia Civil da FCTUC, Portugal. 2011.

Martins, SA.; Ferraz, JM.; Santos, CMT.; Del Menezzi, CHS.; Souza, MR. 2011b. Efeito da usinagem na rugosidade da superfície da madeira de Eucalyptus benthamii. Floresta e Ambiente 18(2):135-143.

Moura, LF.; Hernández, RE. 2005. Evaluation of varnish coating performance for two surfacing methods on sugar maple wood. Wood and Fiber Science 37(2):355-366.

Muenchow, J. 2002. Os passos do processo de colagem lateral e colagem por face em alta frequência. Material técnico - Franklin International. 10 p.

Murmanis, L.; River, BH.; Stewart, H. 1983. Microscopy of abrasive-planed and knife-planed surfaces in wood-adhesive bonds. Wood and Fiber Science 15(2):102-115.

Nascimento, AM.; Lelis, RCC.; Costa, DL.; Oliveira, CS. 2002. Comportamento de ligações adesivas em madeiras de reflorestamento. Floresta e Ambiente 9(1):54-62.

Ozdemir, T.; Hiziroglu, S. 2007. Evaluation of surface quality and adhesion strength of treated solid wood. Journal of Materials Processing Technology 186(1-3):311-314.

Pereira, JCD.; Schaitza, EG.; Shimizu, J. 1997. Características físicas, químicas e rendimento da destilação seca da madeira de Eucalyptus benthamii. Embrapa 35: 2 p.

Pincelli, ALPSM.; Brito, JO.; Corrente, JE. 2002. Avaliação da termorretificação sobre a colagem na madeira de Eucalyptus saligna e Pinus caribaea var. hondurensis. Scientia Forestalis (61):122-132.

Plaster, OB.; Oliveira, JTS.; Abrahão, CP.; Braz, RL. 2008. Comportamento de juntas coladas da madeira serrada de Eucalyptus sp. Cerne 14(3):251-258.

Purbond. 2007. BoletimTécnico PURWELD ${ }^{\circledR}$ 1052. Suiça: Purbond - Adhesive systems for engineered wood. $1 \mathrm{p}$.

River, BH.; Okkonen, EA. 1991. Delamination of edge-glued wood panels: Moisture effects. U.S. Department of Agriculture, Forest Service, Forest Products Laboratory. 11 p.

Rocha, MP. 2000. Eucalyptus grandis Hill ex Maiden e Eucalyptus dunnii Maiden como fontes de matéria prima para serrarias. Tese (Doutorado em Ciências Florestais) Universidade Federal do Paraná, Curitiba. 185 p. 
Serpa, PN.; Vital, BR.; Della Lucia, RM.; Pimenta, AS. 2003. Avaliação de algumas propriedades da madeira de Eucalyptus grandis, Eucalyptus saligna e Pinus elliottii. Revista Árvore 27(5):723-733.

Serrano, LJP. 2009. Resistência à tração da madeira e resistência ao cisalhamento no plano de cola, seus impactos na geometria do dente e propriedades mecânicas de emendas dentadas. Dissertação (Mestrado em Recursos Florestais) Escola Superior de Agricultura "Luiz de Queiroz", Piracicaba. 96 p.

Soares, NS.; Rezende, AM.; Silva, ML.; Moura, AD. 2011. Respectivas dos negócios florestais em 2011. Centro de Inteligência em Florestas. 8 p.

Sulaiman, O.; Hashim, R.; Subari, K.; Liang, CK. 2009. Effect of sanding on surface roughness of rubberwood. Journal of Materials Processing Technology 209(8):3949-3955.

Vassiliou, V.; Barboutis, I.; Karastergiou, S. 2007. Effect of PVAc bonding on finger-joint strength of steamed and unsteamed Beech Wood (Fagus sylvatica). Journal of Applied Polymer Science 103(3):1664-1669.

Vital, BR.; Maciel, AS.; Della Lucia, RM. 2006. Qualidade de juntas coladas com lâminas de madeira oriundas de três regiões do tronco de Eucalyptus grandis, Eucalyptus salignae Pinus elliottii. Revista Árvore 30(4):637-644.

Vrazel, M.; Sellers JR, T. 2004. The effects of species, adhesive type, and cure temperature on the strength and durability of a structural finger-joint. Forest Products Journal 54(3):66-75.

Özçifçi, A.; Yapici, F. 2008a. Effects of machining method and grain orientation on the bonding strength of some wood species. Journal of Materials Processing Technology 202(1-3):353-358.

Özçifçi, A.; Yapici, F. 2008b. Structural performance of the finger-jointed strength of some wood species with different joint configurations. Construction and Building Materials 22(7):1543-1550. 